\title{
Pathogenicity of the root-knot nematode Meloidogyne javanica on potato
}

\author{
N. Vovlas ${ }^{a}$, D. Mifsud ${ }^{b}$, B. B. Landa ${ }^{c}$ and P. Castillo ${ }^{d *} \dagger$ \\ a/stituto per la Protezione delle Piante, Sezione di Bari, Consiglio Nazionale delle Ricerche (C.N.R.), 70126 Bari, Italy; ${ }^{\mathrm{b}}$ Department of \\ Plant Health, Agricultural Research and Development Centre, Ghammieri, Marsa CMR 01, Malta; 'Departamento de Agronomía, \\ Escuela Técnica Superior de Ingenieros Agrónomos y de Montes, Universidad de Córdoba, Apartado 3048, 14080 Córdoba, Spain; and \\ 'Instituto de Agricultura Sostenible, Consejo Superior de Investigaciones Científicas (C.S.I.C.), Apartado 4084, 14080 Córdoba, Spain
}

\begin{abstract}
Host-parasite relationships and pathogenicity of Meloidogyne javanica on potatoes (newly recorded from Malta) were studied under glasshouse and natural conditions. Potato cvs Cara and Spunta showed a typical susceptible reaction to M. javanica under natural and artificial infections, respectively. In potato tubers, M. javanica induced feeding sites that consisted of three to four hypertrophied giant cells per adult female. Infection of feeder roots by the nematode resulted in mature large galls which usually contained at least one mature female and egg mass. In both tubers and roots, feeding sites were characterized by giant cells containing granular cytoplasm and many hypertrophied nuclei. Cytoplasm in giant cells was aggregated alongside the thickened cell walls. Stelar tissues within galls appeared disorganized. The relationship between initial nematode population density $(P)\left[0-64\right.$ eggs + second-stage juveniles $(\mathrm{J} 2 \mathrm{~s})$ per $\mathrm{cm}^{3}$ soil $]$ and growth of cv. Spunta potato seedlings was tested under glasshouse conditions. A Seinhorst model $\left[y=m+(1-m) z^{(P-T)}\right]$ was fitted to fresh shoot weight and shoot height data of nematode-inoculated and control plants. Tolerance limits $(T)$ for fresh shoot weight and shoot height of cv. Spunta plants infected with M. javanica were 0.50 and 0.64 eggs $+\mathrm{J} 2 \mathrm{~s}$ per $\mathrm{cm}^{3}$ soil, respectively. The $m$ parameter in that model (i.e. the minimum possible $y$-values) for fresh shoot weight and shoot height were $0 \cdot 60$ and $0 \cdot 20$, respectively, at $P=64$ eggs $+\mathrm{J} 2 \mathrm{~s} \mathrm{per} \mathrm{cm}^{3}$ soil. Root galling was proportional to the initial nematode population density. Maximum nematode reproduction rate was 51.2 at a moderate initial population density $(P=4$ eggs $+\mathrm{J} 2 \mathrm{~s}$ per $\mathrm{cm}^{3}$ soil).
\end{abstract}

Keywords: histopathology, host-parasite relationships, nematode reproduction, Solanum tuberosum, threshold level

\section{Introduction}

Root-knot nematodes (Meloidogyne spp.) can severely damage and cause significant losses in potato (Solanum tuberosum), in both warm and cool climates, depending upon the nematode species (Brodie et al., 1993). Besides direct yield losses, root-knot nematodes may cause indirect damage in the form of blisters on tubers, as well as brown spots in tuber flesh where the maturing egg mass is located directly under the epidermis. These deformations and blemishes make tubers unmarketable and, more importantly, facilitate dissemination of the pathogen in infected seed tubers to new areas. Although many species of Meloidogyne are known to infect potato, only six are considered to be of global importance: Meloidogyne chitwoodi, M. fallax, M. hapla, M. arenaria, M. incognita

*To whom correspondence should be addressed.

†E-mail:ag1cascp@uco.es

Accepted 20 April 2005 and M. javanica (Netscher, 1970; Jatala \& Bridge, 1990; Brodie et al., 1993; Molendijk \& Mulder, 1996). The first three of those six species are found in cool temperate regions, whereas the others are more important in warm temperate, tropical and subtropical regions of the world (Brodie et al., 1993).

Infection of potato tubers by Meloidogyne spp. has been reported previously in Argentina (Chaves \& Torres, 2001), Brazil (Charchar, 1997), Florida (Chitwood, 1949), Japan (Nakasono et al., 1990), Libya (Dabaj \& Khan, 1981), Rhodesia (now Zimbabwe; Mitchell et al., 1971), Saudi Arabia (Al-Hazmi et al., 1993) and Turkey (Cinarli \& Eterkin, 1996). The present study was carried out on samples of soil heavily infested with $M$. javanica [36 eggs + second-stage juveniles $(\mathrm{J} 2 \mathrm{~s}) \mathrm{cm}^{-3}$ ] at Zabbar in Malta to determine: (i) the histopathology of nematode feeding sites in potato tubers and feeder roots infected by M. javanica; and (ii) the relationship between the initial population density of the nematode and growth of potato seedlings under glasshouse conditions. This is a new occurrence and first record of the nematode in Europe. 


\section{Materials and methods}

\section{Nematode diagnosis}

The root-knot nematode infecting potato tubers and feeder roots of potato $\mathrm{cv}$. Cara was identified by means of microscopic examinations, as well as by analysis of isozyme esterases and by species-specific molecular markers amplified in polymerase chain reaction (PCR) based on sequence-characterized amplified regions (SCARs; Zijlstra et al., 2000). Samples of potato tubers together with rhizosphere and bulk soil were taken with a shovel from the upper $30 \mathrm{~cm}$ of soil from a commercial field at Zabbar, Malta. Second-stage juveniles (J2s) and males were extracted from roots and soil (Coolen, 1979), and females were recovered from infected root tissues and mounted in glycerin. Glycerin-infiltrated specimens were examined by light microscopy for nematode diagnosis. Thirty adult females from this population were analysed by perineal pattern morphology and excretory pore position. Perineal patterns and anterior body portions were prepared as described by Hartman \& Sasser (1985) and examined under a light microscope.

To obtain females for electrophoretic and molecular analyses, the nematode population under study and a reference $M$. javanica population from peach at San Ferdinando in the province of Foggia, Italy, were increased on tomato (Lycopersicon esculentum cv. Rutgers) in a glasshouse at $25 \pm 3^{\circ} \mathrm{C}$. Forty days after inoculation, tomato plants were uprooted, their roots gently washed free of soil, and the root tissues teased apart with forceps and transfer needles to remove adult females.

\section{Esterase isozyme analysis}

One, three or five young egg-laying females of the M. javanica population from Zabbar, Malta, and five young egg-laying females of the M. javanica reference population were macerated in microtubes containing $5 \mu \mathrm{L}$ of $20 \%$ sucrose and $1 \%$ Triton X-100. Electrophoresis was carried out in $7 \times 8-\mathrm{cm}$ homogeneous polyacrylamide gels, $0.75 \mathrm{~mm}$ thick, in a Mini Protean II electrophoresis unit (BIORAD, Madrid, Spain). Gels were stained for esterases with the substrate $\alpha$-naphthyl acetate (Pais et al., 1986).

\section{DNA extraction and PCR assays}

Total genomic DNA was extracted from single adult females according to Castillo et al. (2003). PCR assays were carried out using the SCAR primers and reaction conditions described by Zijlstra et al. (2000). Amplifications were performed with a PTC 100 thermocycler (MJ Research). Amplification products were separated by electrophoresis in $1.5 \%$ agarose gels in $1 \times$ TAE buffer for $2-3 \mathrm{~h}$ at $100 \mathrm{~V}$, stained with ethidium bromide and visualized under UV light. The 0·1-kb DNA ladder XIV size marker (Roche Diagnostics, Germany) was used for electrophoresis. Reactions were repeated at least twice and always included negative controls (no DNA) and positive control
DNA from $M$. arenaria and $M$. incognita adult females from olive nurseries (Nico et al., 2002).

\section{Histopathology}

Plants of potato cv. Spunta were artificially inoculated with the sampled $M$. javanica population and incubated in a glasshouse at $25 \pm 3^{\circ} \mathrm{C}$ for 60 days. Tubers of potato cv. Cara naturally infected by M. javanica at Zabbar (Malta), together with feeder roots from artificially infected cv. Spunta potatoes, were selected for histopathological studies. Small portions $(5 \times 5 \times 5 \mathrm{~cm})$ of the outermost layer (5-8 $\mathrm{mm}$ depth) of naturally infected potato tubers, including the vascular ring, as well as artificially infected feeder roots (4-5 $\mathrm{mm}$ long), were gently washed free of soil and debris and the galled tissues, together with portions of healthy tuber and feeder roots, were selected for histological examination. Tissues were fixed in formaldehyde chromoacetic solution for $48 \mathrm{~h}$, dehydrated in a tertiary butyl alcohol series (40-70-85-90-100\%), embedded in paraffin with a melting point of $58^{\circ} \mathrm{C}$ and sectioned with a rotary microtome. Sections $10-12 \mu \mathrm{m}$ thick were placed on glass slides, stained with safranin and fast-green, mounted permanently in a $40 \%$ xylene solution of a polymethacrylic ester (Synocril 9122X), examined microscopically and photographed (Johansen, 1940).

\section{Relationship between inoculum density and plant growth}

Inoculum of M. javanica from Zabbar was increased on cv. Rutgers tomato plants inoculated as described above and maintained in a glasshouse adjusted to $25 \pm 3^{\circ} \mathrm{C}$. Inoculum was obtained by extracting eggs $+\mathrm{J} 2 \mathrm{~s}$ using $1 \%$ sodium hypochlorite solution (Hussey \& Barker, 1973). Two months after inoculation, when egg masses were well formed in the tomato roots, the inoculated plants were uprooted and their roots gently washed free of soil and finely chopped. To estimate the numbers of eggs $+\mathrm{J} 2 \mathrm{~s}$ in the chopped tissue, six $5 \mathrm{~g}$ aliquots of infected chopped roots were suspended in a $1 \%$ aqueous solution of sodium hypochlorite in $100 \mathrm{~mL}$ jars for $4 \mathrm{~min}$ (Hussey \& Barker, 1973) and all the eggs and J2s in the suspension were counted using a Peter's $1 \mathrm{~mL}$ counting slide. For inoculation, chopped infected roots were thoroughly mixed with $2 \mathrm{~kg}$ of steam-sterilized sandy soil and this mixture was combined in different proportions with a potting medium of steam-sterilized sandy soil $(87.5 \%$ sand, $5 \%$ silt, $5 \%$ clay and $2.5 \%$ organic matter) to obtain a range of increasing population densities: $0,0 \cdot 125,0 \cdot 25,0 \cdot 5,1,4$, 16 and 64 eggs $+\mathrm{J} 2 \mathrm{~s}$ per $\mathrm{cm}^{3}$ soil (Di Vito et al., 1986).

Single-bud pregerminated seed tubers of potato $\mathrm{cv}$. Spunta with good root primordials were planted singly in $500 \mathrm{~mL}$ clay pots filled with $500 \mathrm{~g}$ of infested soil mixture. Plants were incubated in a glasshouse at $25 \pm 3^{\circ} \mathrm{C}$. There were six replicated pots for each level of inoculum density, arranged in a randomized complete block design. Plants in pots were watered as needed and fertilized with $100 \mathrm{~mL}$ of a $0 \cdot 1 \%, 20-5-32+$ micronutrients hydro-sol 
fertilizer (Haifa Chemicals Ltd, Israel) solution every week. Data on the appearance of symptoms of nematode attack (stunting and yellowing) were recorded during the experiment. Sixty days after planting, fresh shoot weight and total plant shoot height were measured. Plants were uprooted and the roots were washed free of soil and weighed. Root infection by the nematode was assessed by estimating root gall severity (RGS) on a $0-5$ scale: 0 , no galls; 1 , one to five galls; 2 , six to 20 small galls; 3 , more than 20 galls homogeneously distributed in the root system; 4 , reduced and deformed root system with some large galls; and 5, completely deformed root system with few but large galls (Di Vito et al., 1979). Eggs and J2s in the egg masses in roots were extracted by the sodium hypochlorite method (Hussey \& Barker, 1973) and counted. Nematodes in soil were extracted by a modification of Coolen's method (Coolen, 1979). The final nematode population density $\left(P_{\mathrm{f}}\right)$ was calculated as the total number of nematodes extracted from roots and soil.

\section{Statistical analysis}

The relationship between the initial nematode population density $(P)$ and plant growth (indicated by fresh shoot weight and total plant height) was determined by fitting the data to the Seinhorst model: $y=m+(1-m) z^{(P-T)}$ when $P$ $\geq T$, and $y=1$ when $P<T$ (Seinhorst, 1965, 1979). In this model, $y$ is the relative value of the plant growth parameter; $m$ is the minimum value of $y$ (at a very large initial nematode population density); $P$ is the initial nematode population density; $T$ is the tolerance limit (initial population at which plant growth is not impaired); and $z$ is a constant $<1$ reflecting nematode damage, with $z^{-T}=1.05$ (Seinhorst, 1965, 1979). The Seinhorst equation was fitted using the SEINFIT program (Viaene et al., 1997). The coefficient of determination $\left(R^{2}\right)$ and the residual sum of squares were used to indicate the goodness-of-fit of data to the model.

The experiment was performed twice. Similarity among experiments was tested by preliminary analyses of variance using experimental runs as factors, which allowed the experiment $\times$ treatment interaction to be determined. This interaction was not significant $(P=0.05)$ and allowed data to be combined for analyses of variance and fitting to the Seinhorst model. Data on root gall severity (RGS), final nematode population $\left(P_{\mathrm{f}}\right)$ and reproduction rate $\left(R_{\mathrm{f}}=\right.$ final population/initial population) were normalized before analysis by transforming them into $\log _{10}(X+1)$ (Gomez \& Gomez, 1984). Analyses of variance were carried out using STATISTIX $8 \cdot 0$ (NH Analytical Software, USA). Means of RGS, $P_{\mathrm{f}}$ and $R_{\mathrm{f}}$ values were compared using Fisher's protected leastsignificant-difference test (LSD) at $P=0 \cdot 05$.

\section{Results}

\section{Symptoms and nematode diagnosis}

Potato cv. Cara plants in commercial fields at Zabbar (Malta) showed severe yellowing, decline (Fig. 1a) and heavily damaged tubers. Infected tubers had numerous blisters on the tuber surface (Fig. 1b and c) that usually contained one or more Meloidogyne females, males and egg masses with eggs (Fig. 1d and e). A mean population density of 8889 eggs $+\mathrm{J} 2 \mathrm{~s} / \mathrm{g}$ of infected tuber tissue (based on the total weight of small-sized tubers) was estimated.

Morphological observations based on J2s, male stylet knobs, features of the female perineal pattern and excretory pore position/stylet length ratio matched typical traits of M. javanica. Isozyme electrophoretic analyses of the sampled young egg-laying females revealed three esterase bands identical to the esterase phenotype of the reference M. javanica (Fig. 2a). Similarly, PCR assays (with primer set $\mathrm{Fj} / \mathrm{Rj}$ ) using DNA extracted from potato nematodes in Malta and from the M. javanica reference isolate from peach gave rise to the $M$. javanica marker amplicon of 670 bp (Zijlstra et al., 2000) (Fig. 2b, lanes 3-5 and 1-2, respectively). No amplification occurred with $M$. arenaria or M. incognita DNA, or with the control (Fig. 2b, lanes $6-7,8-9$ and 10 , respectively).

\section{Histopathology}

The irregular swellings induced by M. javanica on potato tubers (cv. Cara) and the galls on feeder roots (cv. Spunta) varied in size and location. Usually, irregular blisters covering $50-60 \%$ of the tuber surface were present on some $80 \%$ of sampled tubers, giving them a warty appearance (Fig. 1b-d). Most of the infected tissues randomly selected for examination contained an egg mass (Fig. 1g); however, adult males and up to four mature globose females were found associated with the same feeding site in many cases. Additionally, similar infections by adult females of M. javanica were observed in several potato tubers without external symptoms of nematode attack. Histopathological observations on infected cv. Cara tubers revealed well established feeding sites located in the outermost layer of the tuber that included the vascular ring (Fig. 1d). Each adult female was surrounded by three to six large giant cells (originating from protoxylematic cells) showing thickened cell walls, granulated cytoplasm and numerous hypertrophied nuclei and nucleoli (Fig. 1f). Nematode bodies and egg masses containing 0-255 eggs were observed in the internal tuber tissues.

Galls on artificially infected feeder roots of cv. Spunta occurred either singly or in clusters, which encircled the entire root. Occasionally, an egg mass was found inside the cortical root tissues (Fig. 1g), but the majority of egg masses were observed at the root surface. Comparative histological observations of healthy and M. javanicainfected feeder roots of cv. Spunta showed cellular alterations in tissues of the cortex, endodermis, pericycle and stele induced by the nematode. In the permanent feeding sites, each adult female was surrounded by three to four large giant cells showing granulated cytoplasm and numerous hypertrophied nuclei and nucleoli. Nematodeinduced formation of large multinucleate giant cells adjacent to the stele tissues was observed in all infected potato feeder roots. This formation modified the internal 

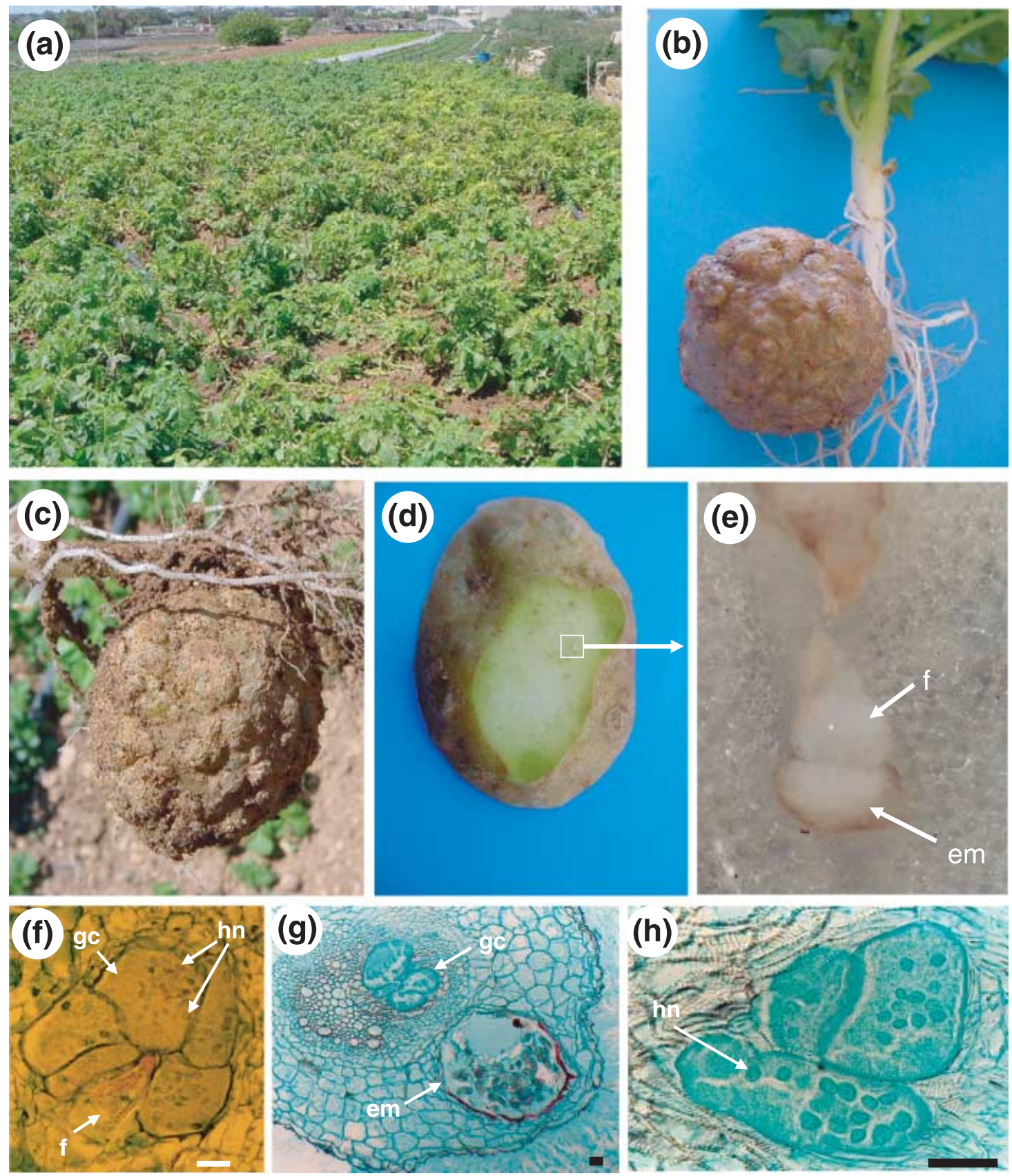

Figure 1 (a) Stunting and yellowing of potato cv. Cara plants severely affected by Meloidogyne javanica in a commercial field at Zabbar, Malta. $(b, c)$ Diseased potato tubers naturally infected by M. javanica showing strong deformation of the outermost layer of the tuber. (d) Section of potato tuber showing numerous adult females with mature egg masses. (e) Higher magnification of (d). (f) Feeding site on tuber induced by nematode female. (g, h) Feeder roots of potato cv. Spunta infected by M. javanica. em, egg-mass; f, adult female; gc, giant cells; hn, hypertrophied nuclei. Scale bars: (f) $200 \mu \mathrm{m}$; $(\mathrm{g}, \mathrm{h}) 50 \mu \mathrm{m}$.

structure of the vascular cylinder, causing extensive distortion, as well as disorganization of the root cortex (Fig. 1g). Giant cells showed dense cytoplasm and variable numbers of hypertrophied nuclei (15-25) and nucleoli (Fig. 1h). Hyperplasia of tissues adjacent to giant cells contributed to formation of root galls.

\section{Relationship between inoculum density and plant} growth

Inoculation of potato cv. Spunta with M. javanica impaired plant growth at all nematode inoculum densities in the study (Fig. 3). The relationship between fresh shoot weight and 

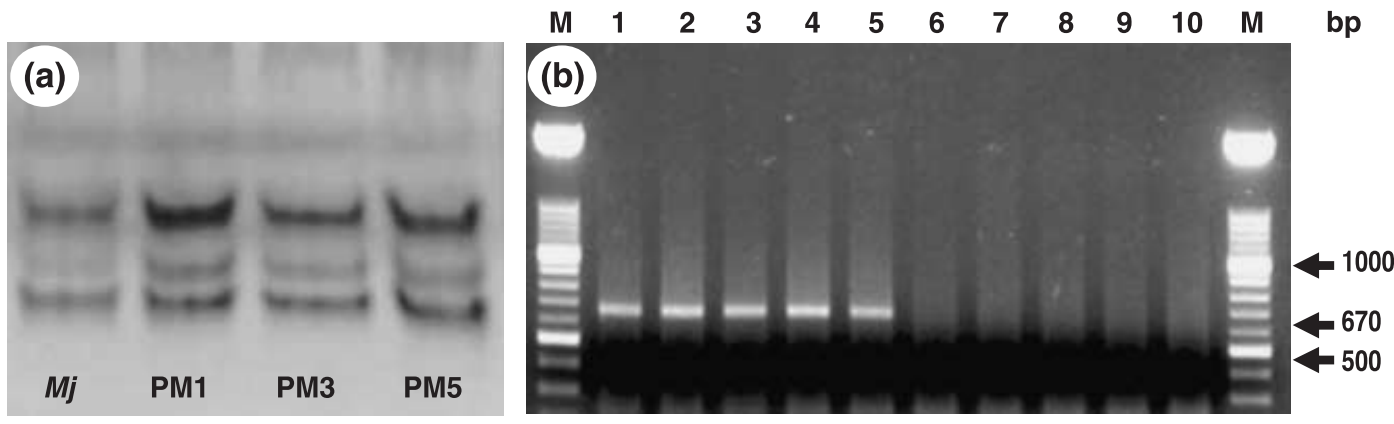

Figure 2 (a) Esterase electrophoresis pattern of protein homogenates from one, three and five egg-laying females (PM1, PM3 and PM5, respectively) of Meloidogyne javanica infecting potato cv. Cara in Malta, and a single young egg-laying female ( $\mathrm{Mj}$ ) of a reference isolate of $M$. javanica. (b) PCR amplification product using primers $\mathrm{Fj}$ and $\mathrm{Rj}$ and 1-10 $\mathrm{ng}$ of template DNA of Meloidogyne isolates: lanes 1-2, M. javanica reference isolate from peach; lanes 3-5, M. javanica from potato in Zabbar, Malta; lanes 6-7, M. arenaria from olive nurseries in Spain; lanes 8-9, M. incognita from olive nurseries in Spain; lane 10, control (no template DNA).

total shoot height of plants and the initial nematode population density in soil was adequately described by the Seinhorst equation, with $R^{2}$ values ranging from 0.672 to 0.747 (Fig. 3a and b). Plant stunting and yellowing caused by $M$. javanica, and reduction of plant shoot growth, were obvious by 30 days after inoculation with 16 eggs $+\mathrm{J} 2 \mathrm{~s}$ per $\mathrm{cm}^{3}$ soil. Forty-five days after inoculation, all plants inoculated with more than 4 eggs $+\mathrm{J} 2 \mathrm{~s}$ per $\mathrm{cm}^{3}$ soil showed stunting and yellowing. The tolerance limits $(T)$ of potato to $M$. javanica were 0.50 and 0.64 eggs $+\mathrm{J} 2 \mathrm{~s}$ per $\mathrm{cm}^{3}$ soil for fresh shoot and total shoot weight, respectively (Fig. 3a and $\mathrm{b})$. The minimum possible relative values $(m)$ for fresh shoot and total shoot weight were $0 \cdot 60$ and $0 \cdot 20$, respectively, at $P=64$ eggs $+\mathrm{J} 2 \mathrm{~s}$ per $\mathrm{cm}^{3}$ soil (Fig. $3 \mathrm{a}$ and b). The maximum nematode reproduction rate $\left(R_{\mathrm{f}}\right)$ was 51.2 at a moderate initial population density of 4 eggs $+\mathrm{J} 2 \mathrm{~s}$ per $\mathrm{cm}^{3}$ soil. In general, the reproduction rate increased as the initial nematode population increased up to 1 egg $+\mathrm{J} 2$ per $\mathrm{cm}^{3}$ soil, and decreased at the highest initial nematode population (Table 1). The highest final population density was found in plants infected with the highest initial population density (Table 1). Similarly, the severity of root galling of potato feeder roots increased with the increase in initial nematode population, with the highest value at 64 eggs + $\mathrm{J} 2 \mathrm{~s}$ per $\mathrm{cm}^{3}$ soil (Table 1 ).

\section{Discussion}

Accurate identification of Meloidogyne spp. infecting potato tubers in potato-growing areas is a prerequisite for quarantine measures, the efficient use of host plant resistance and effective management of these nematodes on potato. Similarly, information on plant growth impairment and yield losses caused by root-knot nematodes is of use in implementing effective integrated management programmes, as well as a prerequisite for farmers to be aware of the importance of managing the diseases caused by these nematodes. Therefore, the severe infections of potato tubers by M. javanica found at Zabbar (Malta) and the severe potato growth impairment caused by this nematode reported in this work highlight the potential risk of spread
Table 1 Relationship between initial population density of Meloidogyne javanica and root galling, final population density and reproduction rate on seed potato cv. Spunta, 50 days after inoculation

\begin{tabular}{|c|c|c|c|c|}
\hline $\begin{array}{l}\text { Initial } \\
\text { population } \\
\text { density }(P)^{\mathrm{a}}\end{array}$ & $\begin{array}{l}\text { Population } \\
\text { density } \\
(P) \text { per pot }\end{array}$ & $R G S^{b}$ & $P_{\mathrm{f}}$ & $R_{f}^{\mathrm{c}}$ \\
\hline 0.125 & $62 \cdot 5$ & $0.75 d$ & $310 d$ & $4.9 \mathrm{c}$ \\
\hline 0.25 & 125 & $1.5 \mathrm{c}$ & $591 d$ & $4.7 \mathrm{C}$ \\
\hline 0.5 & 250 & $3.0 \mathrm{~b}$ & $3825 \mathrm{c}$ & $15 \cdot 3 b$ \\
\hline 1 & 500 & $3.0 \mathrm{~b}$ & $6680 \mathrm{c}$ & $13.4 \mathrm{~b}$ \\
\hline 4 & 2000 & $4.5 a$ & $102353 b$ & $51 \cdot 2 \mathrm{a}$ \\
\hline 16 & 8000 & $4.75 a$ & $403085 a$ & $50 \cdot 4 a$ \\
\hline 64 & 32000 & $5 \cdot 0 \mathrm{a}$ & $619213 a$ & $19 \cdot 4 \mathrm{~b}$ \\
\hline
\end{tabular}

${ }^{\text {a }}$ Pregerminated potato cv. Spunta seed tubers were planted (one per pot) in a potting mixture infested with the appropriate $P$ (numbers of eggs + second-stage juveniles per $\mathrm{cm}^{3}$ soil). Plants were grown in a glasshouse adjusted to $25 \pm 3^{\circ} \mathrm{C}$ for 60 days. Data are the average of two trials each with six replicated plants per treatment combination.

Means followed by the same letter do not differ significantly $(P>0.05)$ according to Fisher's protected LSD test.

${ }^{b}$ Severity of root galling (RGS) was rated on a $0-5$ scale: 0 , no galls; 1 , one to five galls; 2 , six to 20 galls; 3 , more than 20 galls homogeneously distributed in the root system; 4 , reduced and deformed root system with some large galls; and 5, completely deformed root system with a few large galls.

${ }^{\mathrm{c}} R_{\mathrm{f}}$ (nematode reproduction rate $)=P_{\mathrm{f}}$ (final nematode population per plant)/P.

of this pathogen from infected early season potatoes to the potato-growing areas of the European Union.

The results of the histopathological studies indicate a typical susceptible reaction of potato cvs Cara and Spunta to infection by M. javanica. The extensive galling on potato tubers naturally infected by the nematode suggests that environmental conditions in the Mediterranean Basin are highly conducive for infection of potato tubers, thus making it possible for the pathogen to be disseminated in them to new areas (Nakasono et al., 1990). In particular, special care must be taken with seed-potato production in Meloidogyne-infested fields, since seed tubers without 

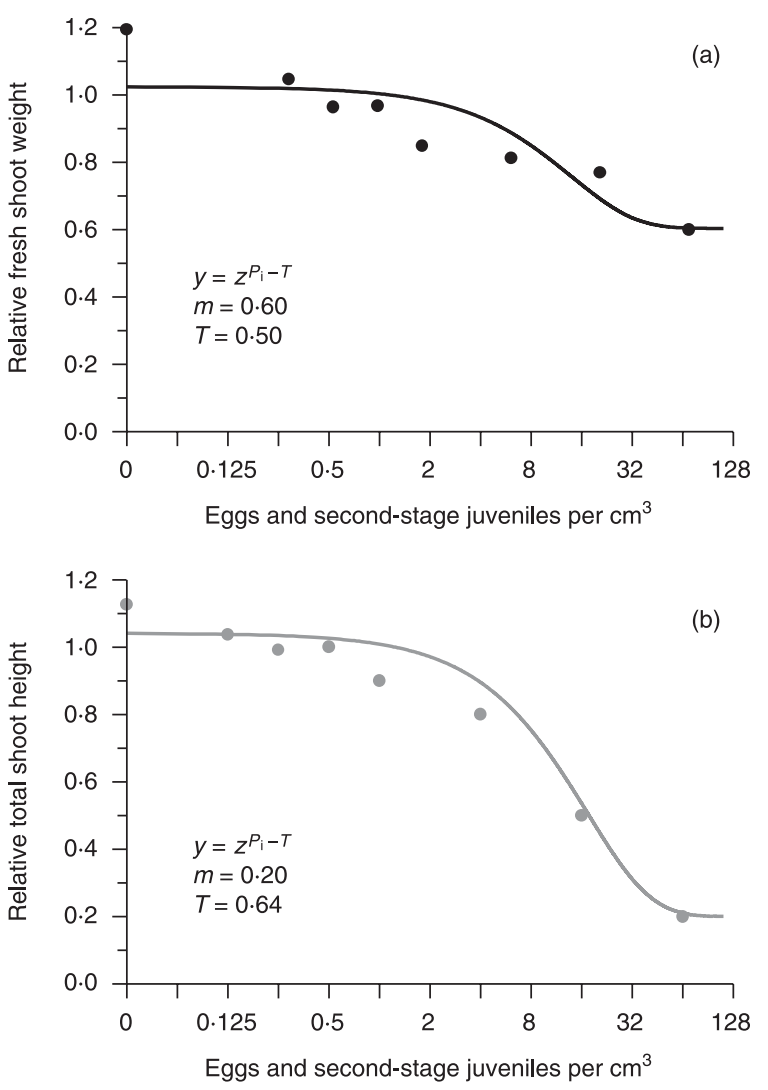

Figure 3 Relationship between initial population densities $\left(P_{\mathrm{i}}\right)$ of Meloidogyne javanica and relative fresh shoot weight (a) and shoot height (b) of potato cv. Spunta plants grown in pots at $25 \pm 3^{\circ} \mathrm{C}$ in the glasshouse for 60 days. Each point is the mean of two trials with six replicated plants each. Lines represent the predicted function calculated by fitting the Seinhorst model to data of fresh shoot weight and shoot height. For the fitted model of fresh shoot weight (a), $R^{2}=0.6718$ and sum of squares $=0.7495$; for shoot height $(b)$, $R^{2}=0 \cdot 7469$ and sum of squares $=0 \cdot 1771$.

surface galling at harvest or initial storage may still be potential carriers of Meloidogyne egg-laying females, as demonstrated by Jatala et al. (1982). The observations of the present study indicate that symptoms may develop internally, resulting in external symptoms being visible only after several months of storage (Jatala et al., 1982). Therefore, visual examination of tubers is not always accurate enough for diagnosis of infection, while extraction of nematodes from tubers undoubtedly improves detection and confirms infection (Viaene et al., 2004).

Giant cells and tissue modifications induced by nematode infections were found to sequester nutrients from the host plant and limit water and nutrient translocation from infected roots to above-ground plant tissues (Hussey \& Williamson, 1997) with subsequent plant growth impairment. The development and parasitic habit of $M$. javanica observed in potato tubers and feeder roots in the present study were similar to those reported for M. incognita (Vovlas et al., 1994), suggesting that infection by M. javanica has the potential to severely damage potato. The severity of root galling of cv. Spunta feeder roots, as well as the severe impairment of plant growth with increase in initial inoculum densities in soil, confirmed that $M$. javanica has great damage potential and reproductive capacity on potato, and agreed with data reported by Di Vito et al. (2003) for several susceptible Solanum spp.

The Seinhorst function adequately described the pathogenic relationship of M. javanica inoculum on potato. Using this model, the estimated tolerance limit of this plant to the nematode was as low as 0.50 and 0.64 eggs $+\mathrm{J} 2 \mathrm{~s}$ per $\mathrm{cm}^{3}$ soil (equivalent to 125 and 160 eggs $+\mathrm{J} 2 \mathrm{~s}$ per 250 $\mathrm{cm}^{3}$ soil) for fresh shoot weight and total shoot height, respectively. An initial population density of this pathogen exceeding 64 eggs $+\mathrm{J} 2 \mathrm{~s}$ per $\mathrm{cm}^{3}$ soil may decrease shoot height by $80 \%$ compared with noninfected control plants. Preplant inoculum thresholds for root-knot nematodes in potato were estimated at 1 egg per $250 \mathrm{~cm}^{3}$ soil for $M$. chitwoodi (Santo et al., 1981) and 50 eggs per $250 \mathrm{~cm}^{3}$ soil for M. hapla (Brodie et al., 1993). Thus, the tolerance limits in the present study of 125 and 160 eggs $+\mathrm{J} 2 \mathrm{~s}$ per $250 \mathrm{~cm}^{3}$ soil for fresh shoot weight and shoot height of potato $\mathrm{cv}$. Spunta, respectively, indicate that under conditions conducive to infection, $M$. javanica is less aggressive on potato than M. chitwoodi and M. hapla. Nevertheless, damage by M. hapla on potato has been reported in the northeastern and north-central USA, eastern and central Canada, and in the Netherlands. It has also recently been found to increase as a result of reduction in the use of soil pesticides and cereal crop rotation (Brodie et al., 1993; Wishart et al., 2002).

The reduction of nematode reproduction rate with increasing initial nematode inoculum density has been reported for infections of several crops by Meloidogyne spp. (Di Vito et al., 1986, 2004). Reproduction rates of M. javanica on potato at an initial inoculum density of $1 \mathrm{egg}+\mathrm{J} 2$ per $\mathrm{cm}^{3}$ soil were similar to those observed for M. chitwoodi, and higher than those for M. fallax or M. hapla, on several potato cultivars (Van der Beek et al., 1997).

In view of the aggressiveness of M. javanica to potato demonstrated in the present study, management of this nematode species should be considered when implementing integrated pest management programmes in potato-growing areas where environmental conditions and potato-culture practices may favour the development of $M$. javanica. The results also highlight the need for additional studies on the resistance of potato to M. javanica. Although some attention was given to screening and breeding for resistance to Meloidogyne spp. in potato (Anter, 1989; Phillis, 1994; Grammatikaki et al., 1999; Berthou et al., 2003; Di Vito et al., 2003), no potato cultivars resistant to these nematodes appear to be available in Europe. This is probably a consequence of the highly variable genetic make-up of Meloidogyne species.

This study shows that $M$. javanica is less aggressive on potato than M. chitwoodi and M. hapla, but nevertheless can severely impair potato growth. Thus, correct diagnosis and estimation of soil population levels of M. javanica, as well as of other root-knot nematodes, should be carried 
out before planting to facilitate the effective integrated management of these nematodes on potato.

\section{Acknowledgements}

The authors thank V. Farrugia for providing the potato samples infected with Meloidogyne for inspection, A. PortaPuglia for help during field surveys, N. Sasanelli (IPP-Bari), R. M. Jiménez-Díaz, J. A. Navas-Cortés (IAS-Córdoba) for help and suggestions, J. Martín Barbarroja for technical assistance and T. C. Paulitz for comments and suggestions. $\mathrm{BBL}$ is the recipient of a Ramón y Cajal grant from the Ministerio de Educación y Ciencia of Spain.

\section{References}

Al-Hazmi AS, Ibrahim AAM, Abdul-Raziq AT, 1993. Distribution, frequency and population density of nematodes associated with potato in Saudi Arabia. Afro-Asian Journal of Nematology 3, 107-11.

Anter EAM, 1989. Susceptibility of certain cultivars of potato, Solanum tuberosum, to infection with Meloidogyne javanica. Assiut Journal of Agricultural Sciences 20, 295-301.

Berthou F, Kouassi A, Bossis M, Dantec JP, Eddaoudi M, Ferji Z, Pellé R, Taghzouti M, Ellisèche D, Mugniery D, 2003. Enhancing the resistance of the potato to southern root-knot nematodes by using Solanum sparsipilum germplasm. Euphytica 132, 57-65.

Brodie BB, Evans K, Franco J, 1993. Nematode parasites of potatoes. In: Evans K, Trudgill DL, Webster JM, eds. Plant Parasitic Nematodes in Temperate Agriculture. Wallingford, UK: CAB International, 87-132.

Castillo P, Vovlas N, Subbotin S, Troccoli A, 2003. A new root-knot nematode, Meloidogyne baetica n. sp. (Nematoda: Heteroderidae), parasitizing wild olive in Southern Spain. Phytopathology 93, 1093-102.

Charchar JM, 1997. Nematoides asociados a cultura da batata (Solanum tuberosum L.) nas principais areas in Brazil. Nematologia Brasileira 21, 49-60.

Chaves E, Torres MS, 2001. Nematodos parásitos de la papa en regiones productoras de papa semilla en la Argentina. Revista Facultad de Agronomía 21, 245-59.

Chitwood BG, 1949. Root-knot nematodes. Part I. A revision of the genus Meloidogyne Goeldi, 1887. Proceedings of the Helminthological Society of Washington 16, 90-104.

Cinarli I, Eterkin NN, 1996. Root-knot nematode Meloidogyne javanica (Treub, 1885) Chitwwod, 1949 damage on russett burbank potato tubers centrifugation-flotation technique. Journal of Turkish Phytopathology 25, 103-7.

Coolen WA, 1979. Methods for the extraction of Meloidogyne spp. \& other nematodes from roots and soil. In: Lamberti F, Taylor CE, eds. Root-Knot Nematodes (Meloidogyne Species) Systematics, Biology and Control. London, UK: Academic Press, 317-29.

Dabaj KH, Khan MW, 1981. Incidence of root-knot disease in tomato and potato and identity of the causal species in the western region of the Libyan Jamahiriya. Libyan Journal of Agriculture 10, 103-9.

Di Vito M, Greco N, Carella A, 1986. Effect of Meloidogyne incognita and importance of the inoculum on the yield of eggplant. Journal of Nematology 18, 487-90.
Di Vito M, Greco N, Carputo D, Frusciante L, 2003. Response of wild and cultivated potato clones to Italian populations of root-knot nematodes Meloidogyne spp. Nematropica 33, 6572.

Di Vito M, Lamberti F, Carella A, 1979. La resistenza del pomodoro nei confronti dei nematodi galligeni: prospettive e possibilitá. Rivista di Agronomia 13, 313-22.

Di Vito M, Vovlas N, Castillo P, 2004. Host-parasite relationships of Meloidogyne incognita on spinach. Plant Pathology 53, 508-14.

Gomez KA, Gomez AA, 1984. Statistical Procedures for Agricultural Research. New York, USA: John Wiley.

Grammatikaki G, Vovlas N, Kaltsikes PJ, Sonnino A, 1999. Response of potato gametoclones to infection of four rootknot nematode (Meloidogyne) species. Russian Journal of Nematology 7, 155-9.

Hartman KM, Sasser JN, 1985. Identification of Meloidogyne species on the basis of differential host test and perineal pattern morphology. In: Barker KR, Carter CC, Sasser JN, eds. An Advanced Treatise on Meloidogyne: Methodology, Vol. II. Raleigh, NC, USA: NCSU Graphics, 69-77.

Hussey RS, Barker KR, 1973. A comparison of methods of collecting inocula of Meloidogyne spp., including a new technique. Plant Disease Reporter 57, 1025-8.

Hussey RS, Williamson VM, 1997. Physiological and molecular aspects of nematode parasitism. In: Barker KR, Pederson GA, Windham GL, eds. Plant and Nematode Interactions. Madison, WI, USA: American Society of Agronomy. 87-108.

Jatala P, Booth RH, Wiersema SG, 1982. Development of Meloidogyne incognita in stored potato tubers. Journal of Nematology 14, 142-3.

Jatala P, Bridge J, 1990. Nematode parasites of root and tuber crops. In: Luc M, Sikora RA, Bridge J, eds. Plant Parasitic Nematodes in Subtropical and Tropical Agriculture. Wallingford, UK: CAB International, 137-80.

Johansen DA, 1940. Plant Microtechnique. New York, USA: McGraw-Hill.

Mitchell BL, Blair BW, Martin GC, 1971. Potatoes in Rhodesia. Part II. Pest of potatoes. Technical Bulletin, Rhodesia Agricultural Journal 11, 25-31.

Molendijk LPG, Mulder A, 1996. The Netherlands, nematodes and potatoes: old problems are here again. Potato Research $39,471-7$.

Nakasono K, Usugi T, Araki M, 1990. Severe galling of potato tubers infected with Meloidogyne javanica and possible role in dissemination. Japanese Journal of Nematology 20, 56.

Netscher C, 1970. Les nématodes parasites des cultures maraichères au Sénégal. Cahiers ORSTOM, Série Biologie 11, 209-29.

Nico AI, Rapoport HF, Jiménez-Díaz RM, Castillo P, 2002. Incidence and population density of plant-parasitic nematodes associated with olive planting stocks at nurseries in southern Spain. Plant Disease 86, 1075-9.

Pais CS, Abrantes IMO, Fernandes MFM, Santos MSNA, 1986. Técnica de electroforese aplicada ao estudo das enzimas dos nemátodes-das-galhas-radiculares, Meloidogyne spp. Ciencia Biologia Ecologia Y Systematica 6, 19-34.

Phillis MS, 1994. Inheritance of resistance to nematodes. In: Bradshaw JE, Lackay GR, eds. Potato Genetics. Wallingford, UK: CAB International, 319-37.

Santo GS, O’Bannon JH, Nycepir AP, Ponti RP, 1981. Ecology and control of root-knot nematodes on potato. Proceedings of 
the 20th Annual Washington Potato Conference, 3-5 February, Moses Lake, Washington, USA. Moses Lake, WA, USA: Washington State Potato Commission, 135-9.

Seinhorst JW, 1965. The relationship between nematode density and damage to plants. Nematologica 11, 137-54.

Seinhorst JW, 1979. Nematodes and growth of plants: formulation of the nematode-plant system. In: Lamberti F, Taylor CE, eds. Root-Knot Nematodes (Meloidogyne Species) Systematics, Biology and Control. London, UK: Academic Press, 231-56.

Van der Beek JG, Vereijken PFG, Poleij LM, Van Silfhout CH, 1997. Isolate-by-cultivar interaction in root-knot nematodes Meloidogyne hapla, M. chitwoodi, and M. fallax on potato. Canadian Journal of Botany 76, 75-82.

Viaene N, Mahieu T, Moens M, 2004. Detection of Meloidogyne chitwoodi in infected potato tubers. Proceedings of the 17th International Symposium European
Society of Nematologists, 14-18 June, Roma, Italy. Leiden, the Netherlands: Brill, 37-8.

Viaene NM, Simoens P, Abawi GS, 1997. SeinFit, a computer program for the estimation of the Seinhorst equation. Journal of Nematology 29, 474-7.

Vovlas N, Grammatikaki G, Sonnino A, 1994. Response of anther culture-derived diploid lines of potato to the root-knot nematode Meloidogyne incognita. Nematologia Mediterranea 22, 237-40.

Wishart J, Phillips MS, Blok VC, 2002. Ribosomal intergenic spacer: a polymerase chain reaction diagnostic for Meloidogyne chitwoodi, M. fallax, and M. hapla. Phytopathology 92, 884-92.

Zijlstra C, Donkers-Venne DTHM, Fargette M, 2000. Identification of Meloidogyne incognita, M. javanica and $M$. arenaria using sequence characterised amplified region (SCAR) based PCR assays. Nematology 2, 847-53. 